\title{
Sinergi Orang Tua dan Anak
}

\author{
Oleh Fathurozi \\ Staf Balai Penelitian dan Pengembangan Agama Semarang
}

Setiap orang tua memimpikan anak-anaknya mendapatkan nilai maksimal setiap mata pelajaran. Lebih mengembirakan lagi ketika sang anak menjadi juara kelas. Demi mencapai impiannya anak-anaknya diikutkan les privat. Bahkan la (orang tua) mengatur waktu belajar anak. Kelihatannya orang tua kurang memperhatikan waktu istirahat dan bermain si anak.

Kesibukan orang tua dalam beraktifitas, seringkali menitipkan anak-anaknya kepada ibu pengganti. Semisal nenek atau orang tua sendiri. Terkadang orang tua merasa bersalah karena tidak bisa menemani aktifitas belajar dan bermain. Wajar saja orang tua selalu menuruti permintaan anak.Namun orang tua harus berikap sewajarnya, jangan sampai anak menjadi manja dan tidak mandiri.

Orang tua (ibu dan ayah) sebagai guru pertama yang akan memberikan asupan nilai-nilai moral, jika orang tua selalu melarang aktifitas si anak, maka menjadikan sang anak cuek dengan lingkungan. Ironis lagi ketika sang anak baru pulang sekolah, orang tua sering kali menyuruhnya untuk tidur, padadal si anak ingin bermain dulu, baru beristirahat.

Merujuk sajak ber judul "Anak Belajar dari Kehidupannya" karya Dorothy Law Nolte yang diterjemahkan oleh Jalaluddin Rakhmat dalam bukunya Islam Aktual; refleksi-sosial seorang cendekiawan Muslim(1998). "Jika anak dibesarkan dengan celaan, ia akan belajar memaki / Jika anak dibesarkan dengan cemoohan, ia akan belajar rendah diri / Jika anak dibesarkan dengan toleransi, ia akan belajar menahan diri / Jika anak dibesarkan dengan pujian, ia akan belajar menghargai / Jika anak dibesarkan dengan sebaik-baiknya perlakuan, ia akan belajar keadilan/Jika anak dibesarkan denganrasa aman, ia akan belajar menaruh kepercayaan / Jika anak dibesarkan dengan dukungan, ia akan belajar menghargai dirinya / Jika anak dibesarkan dengan kasih sayang dan persahabatan, maka ia akan belajar menemukan cinta dalam kehidupan".

Anak sebagai peniru ulung, apa yang dilakukan orang tua akan diikutinya. Jika orang tua bersikap baik, maka anak akan bersikap baik pula. Kita bisa mengamati anak-anak di sekolah jika si anak jahil, cuek, pendiam mungkin disebabkan didikkan orang tua. Karena prilaku si anak merupakan cerminan atau bayangan orang tua.

Terkadang orang tua dalam mendidik anak-anaknya berdasarkan pada pengalaman masa kecilnya. Jika dulu orang tua keras, maka si anak akan didik keras pula. Namun orang tua kurang mengetahui kondisi si anak. Watak anak dulu dengan anak sekarang jelas berbeda. Tak ayal, si anak akan melawan dan lari dari keluarga. Sejatinya orang tua harus mengetahui pola pendidikan modern. 


\section{Tanggung Jawab}

Berdasarkan hasil jajak pendapat yang dilakukan Kompas pada 22-24 April 2015 menunjukkan, mayoritas publik menyadari pentingnya peran orangtua dalam pendidikan anak. Dari 326 responden yang di keluarganya terdapat anak usia sekolah. Tak kurang dari 85 persen responden menyatakan bahwa orangtua dan keluarga memiliki peran paling penting dalam proses pendidikan anak. Hanya 15 persen responden yang menilai peran ini ada di tangan guru dan lingkungan di luar keluarga.

Orang tua yang selalu mendidik anak-anaknya dengan cara menekan mendapatkan kritikan tajam dari comica Fatih Unru, dalam tiap kesempatan, lamenyuarakan hubungan orang tua dan anak.Ketika orangtua menginginkan hal ini bertolak belakang dengan keinginan anak. Fatih juga menekankan soal dunia anak adalah dunia bermain, bukan dunia tidur. "Baru pulang sekolah, baru kita mau main, orang tua bilang anak-anak tidur siang, ketika malam anak-anak disuruh tidur, ketika belum tidur diancam dengan lagu "nina bobo". Bahkan Fatih berpendapat janganjangan anak yang berbakti pada orang tua adalah anak yang suka tidur.

Roger, Cosby dan Sawyers (1995) setiap anak selalu bermain karena dengan main anak akan merasa rileks, senang serta tidak tertekan. Piaget (1962) melihat permainan sebagai suatu media yang dapat meningkatkan perkembangan kognitif anak-anak. Sedangkan Daniel Berlyne (1960),permainan sebagai sesuatu yang mengasyikan dan menyenangkan karena permainan itu memuaskan dorongan penjelajahan kita.

Terbukti dengan raut wajah yang ceria tanpa beban terpancar dari permainan bersama temanteman seusianya. Dengan bermain,anak belajar membangun suatu hubungan sosial dengan anak-anak lain. Namun ide permainan harus muncul dari si anak itu sendiri.

Sebaiknya orang tua melakukan beberapa langkah yakni. Pertama, orang tua memberikan kebebasan anak untuk bermain. Namun orang tua harus mengetahui dimana kebiasaan anaknya bermain atau nongkrong. Secara diam-diam orang tua melakukan survei ke tempat nongkrong si anak, apa tempat itu berbahaya atau tidak. Ketika tempat tersebut kondisinya ramah untuk bergaul, suka rela melepas anak bermain dan setidaknya mengurangi rasa was-was yang selalu menyelimuti pikiran. Sebaliknya, jika berbahaya orang tua dapat mencegahnya. Dengan adanya timbal balik ini akan menimbulkan saling percaya antara orang tuadan anak.

Kedua, sesibuk apapun orang tua harus meluangkan waktu untuk menemani anak balajar dan sesekai mengajak si anak rekreasi. Artinya bahwa kehadiran orang tua memberikan motivasi tersendiri yang tak tergantikan. Ketiga, si anak menginjak sekolah dasar (SD) dan SMP uang jajan diberikan tiap hari.Namun ketika si anak duduk bangkusekolah SMA orang tua, sebaiknya membuatkan surat izin mengemudi (SIM). Hal ini dilakukan untuk mematuhi peraturan kendaraan di jalan raya. Semisal di jalan melanggarsi anak harus dapat menyelesaikan sendiri, orang tua sifatnya memantau.

Selanjutnya orang tua membuatkan anjungan tunai mandiri (ATM) bagi sang anak. Segala sesuatu yangberkaitan kebutuhan sekolah akan diberikan satu bulan sekali lewat transfer bank. Jika belum satu bulan uangnya habis, maka perlu dilakukan audit. Semisal orang tua bertanya uangnya dibelanjakan untuk apa saja?. Ketika jawabannya untuk foto copy makalah, bensin, 
jajan, pulsa, internet dan sebagainya.Jika alasannya dianggap masuk akal, maka orang tua sepatutnya memberikan uang tambahan.Namun ketika habis untuk senang-senang, perlu diberisanksi berupa jatah bulanan dikurangi. Dengan cara ini setidaknya melatih si anak dalam pengelolakeuangannya sendiri.

Terkadang suami atau istri merasa kasihan dan tidak tega melihat si anak. Semisal istri tanpa sepengetahuan suami memberikan uang tambahan dan sebaliknya. Perbuatan ini justru akan menjadikan anak tidak mandiri dan tidak bertanggung jawab.Maka suami istri harus ada kesepakatan terlebih dahulu, agar rencananya tidak berantakan. Jangan sampai menyesal kemudian, ibaratnya nasi sudah menjadi bubur.

Dimuat Harian Bhirawa, 09 Mei 2016

http://harianbhirawa.co.id/2016/05/sinergi-orang-tua-dan-anak/ 